\title{
Age of an Indonesian Fossil Tooth Determined by Electron Paramagnetic Resonance
}

\section{April 2004}

Prepared by

J. S. Bogard

M. E. Murray

Oak Ridge National Laboratory

R. A. Weeks

Vanderbilt University

D. C. Weinand

J. M. Elam

A. Kramer

University of Tennessee - Knoxville 


\title{
DOCUMENT AVAILABILITY
}

Reports produced after January 1,1996, are generally available free via the U.S. Department of Energy (DOE) Information Bridge:

Web site: http://www.osti.gov/bridge

Reports produced before January 1,1996, may be purchased by members of the public from the following source:

\author{
National Technical Information Service \\ 5285 Port Royal Road \\ Springfield, VA 22161 \\ Telephone: 703-605-6000 (1-800-553-6847) \\ TDD: $703-487-4639$ \\ Fax: 703-605-6900 \\ E-mail: info@ntis.fedworld.gov \\ Web site: http://www.ntis.gov/support/ordernowabout.htm
}

Reports are available to DOE employees, DOE contractors, Energy Technology Data Exchange (ETDE) representatives, and International Nuclear Information System (INIS) representatives from the following source:

Office of Scientific and Technical Information

P.O. Box 62

Oak Ridge, TN 37831

Telephone: 865-576-8401

Fax: 865-576-5728

E-mail: reports@adonis.osti.gov

Web site: http://www.osti.gov/contact.html

\begin{abstract}
This report was prepared as an account of work sponsored by an agency of the United States Government. Neither the United States government nor any agency thereof, nor any of their employees, makes any warranty, express or implied, or assumes any legal liability or responsibility for the accuracy, completeness, or usefulness of any information, apparatus, product, or process disclosed, or represents that its use would not infringe privately owned rights. Reference herein to any specific commercial product, process, or service by trade name, trademark, manufacturer, or otherwise, does not necessarily constitute or imply its endorsement, recommendation, or favoring by the United States Government or any agency thereof. The views and opinions of authors expressed herein do not necessarily state or reflect those of the United States Government or any agency thereof.
\end{abstract}




\title{
AGE OF AN INDONESIAN FOSSIL TOOTH DETERMINED BY ELECTRON PARAMAGNETIC RESONANCE
}

\author{
J. S. Bogard \\ M. E. Murray \\ Oak Ridge National Laboratory \\ R. A. Weeks \\ Vanderbilt University \\ D. C. Weinand \\ J. M. Elam \\ A. Kramer \\ University of Tennessee - Knoxville
}

April 2004

\author{
Prepared by \\ OAK RIDGE NATIONAL LABORATORY \\ P.O. Box 2008 \\ Oak Ridge, Tennessee 37831-6285 \\ managed by \\ UT-Battelle, LLC \\ for the \\ U.S. DEPARTMENT OF ENERGY \\ under contract DE-AC05-00OR22725
}





\section{CONTENTS}

Page

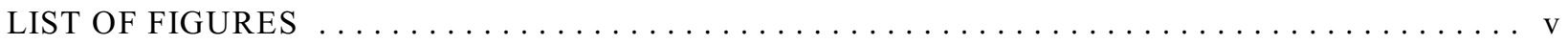

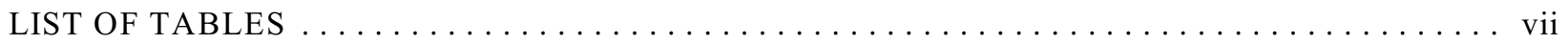

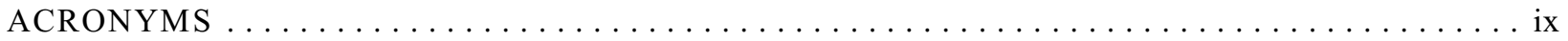

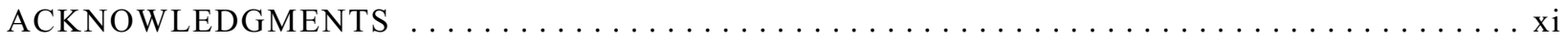

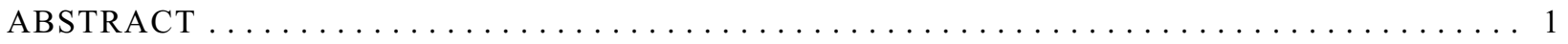

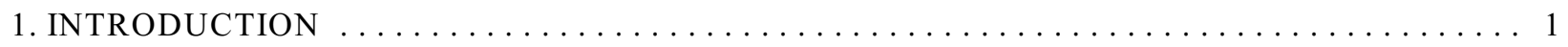

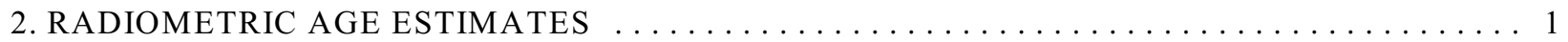

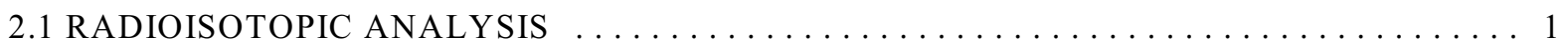

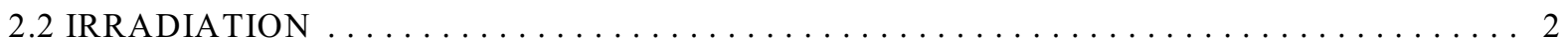

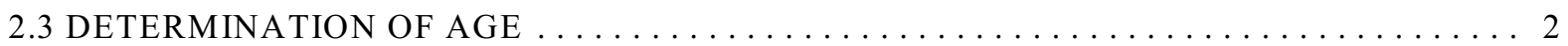

2.4 SOURCES OF UNCERTAINTY OR ERROR IN THE DETERMINATION OF AGE $\ldots \ldots . .3$

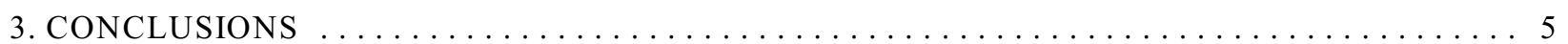

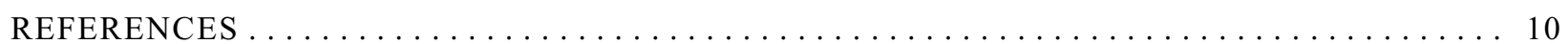





\section{LIST OF FIGURES}

Figure

Page

1 EPR spectrum of a bar sample from a fossil bovid tooth, as recovered. Spectral features used in radiometric age estimation are marked by arrows, with $g=$ 2.0062 (for the field at A), $g=2.0038$ (B), $g=2.0030$ (C), $g=2.0009$ (D) and $g=1.9980$ (E) (all values \pm 0.0005$)$. The H1 doublet $(g=2.0169$ and $g=1.9906)$ was not used to estimate age of the sample. The spectrometer parameters are sweep range, $5 \mathrm{mT}$; field modulation frequency, $100 \mathrm{kHz}$ and amplitude $0.05 \mathrm{mT}$; amplifier gain, $10 \times 10^{3}$; microwave power, $2 \mathrm{~mW} \ldots \ldots \ldots \ldots \ldots \ldots$

2 Electron paramagnetic resonance response of fossil tooth enamel to ionizing radiation. Peaks and inflections in the first derivative of the absorption, 'A' through ' $E$ ', are identified in Figure 1. Responses correspond to a modulation amplitude of $0.05 \mathrm{mT}(0.5 \mathrm{G})$ and gain $=10^{4}$. The response for an added dose of zero is the response of the enamel from accumulated radiation exposure during

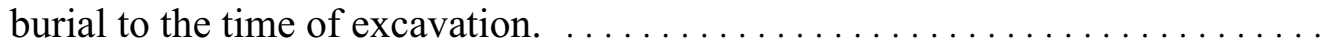





\section{LIST OF TABLES}

Table

Page

1 Radionuclide activity concentrations $(\mathrm{pCi} / \mathrm{g})$ in tooth enamel and contextual

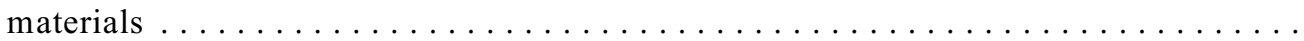

$2 \quad$ Specific activities of the pure radionuclides. $\ldots \ldots \ldots \ldots \ldots \ldots \ldots \ldots \ldots \ldots \ldots$

3 Radionuclide mass concentrations used for dose rate estimates $\ldots \ldots \ldots \ldots \ldots \ldots \quad 7$

4 Dose rate conversions for the naturally occurring radionuclides $\ldots \ldots \ldots \ldots \ldots \ldots$

$5 \quad$ Sample dose rate estimate from incorporated radionuclides $\ldots \ldots \ldots \ldots \ldots \ldots \ldots$

6 Radiation response of excavated tooth enamel for five radio-sensitive EPR resonances

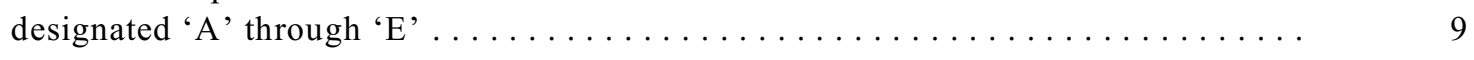

$7 \quad$ Regression parameters from the dose-response curves of Figure $1 \ldots \ldots \ldots \ldots \ldots$ 



\section{ACRONYMS}

CSA006 Cipasang 6, fossil bovid tooth recovered $190 \mathrm{~cm}$ below the hominid tooth designated RH 1

DOSAR Dosimetry Applications Research

EPR Electron paramagnetic resonance

HPGe High purity germanium

ORNL Oak Ridge National Laboratory

ppm Parts per million

RH1 Rancah hominid 1, fossil hominid tooth recovered near Rancah, West Java 



\section{ACKNOWLEDGMENTS}

The authors thank L. A. Boatner, Solid State Division, Oak Ridge National Laboratory (ORNL), for useful discussions about EPR and for the use of the spectrometer in his laboratory. We thank J. A. Kolopus, Solid State Division, ORNL, for his assistance in preparing the fossil dental samples for EPR analyses. This research was supported by grants from the National Science Foundation (SBR-9870751 to Kramer), the Wenner-Gren Foundation for Anthropological Research, Inc., (ICRG-23 to Kramer and Djubiantono, coP.I.s), the L.S.B. Leakey Foundation, and the University of Tennessee Graduate School. Finally, we wish to thank Sekolah Tinggi Teknologi Nasional (STTNas), Yogyakarta, for their sponsorship of our 1999 fieldwork. 



\begin{abstract}
The first fossil hominid tooth recovered during 1999 excavations from the Cisanca River region in West Java, Indonesia, was associated with a series of bovid teeth from a single individual that was recovered $190 \mathrm{~cm}$ beneath the hominid tooth. The age of the fossil bovid teeth was determined using electron paramagnetic resonance (EPR) analysis as part of an effort to bracket the age of the hominid tooth. The EPR-derived age of the bovid teeth is $(5.16 \pm 2.01) \times 10^{5}$ years. However, the age estimate reported here is likely an underestimate of the actual age of deposition since evidence of heating was detected in the EPR spectra of the bovid teeth, and the heating may have caused a decrease in the intensity of EPR components on which the age calculation is based.
\end{abstract}

\title{
1. INTRODUCTION
}

An international, multidisciplinary project undertook paleoanthropological and geological fieldwork near the village of Rancah in West Java during the summer of 1999 (Kramer et al., 2000). The field team conducted excavations and surveys at two sites along the Cipasang and Cisanca Rivers. A number of large vertebrate fossils were recovered from both excavations and surface surveys of the surrounding areas. The most significant discovery was a hominid incisor (designated 'RH1') found in situ, more than three meters below the surface at Cisanca. This is the first fossil hominid recovered from West Java and one of the very few Indonesian hominids to be produced as the result of a controlled excavation (Kramer et al., 2001, 2002). Comparisons of RH1 to samples of great apes, modern humans and the fossil hominid H. erectus suggest affinities with the latter species (Kramer et al., 2004). A series of bovid teeth from a single individual was recovered $190 \mathrm{~cm}$ beneath the hominid tooth. We employed electron paramagnetic resonance spectroscopy (EPR, also known as electron spin resonance or ESR) dating of tooth enamel (see Cetin, et al. [1994]; Curnoe, et al. [2001]; Geyh and Schleicher [1990]; Grün, et al. [1987]; Schwarcz and Grün [1993]; and Weinand, et al. [2000]) from one of the fossil bovid teeth (designated 'CSA006') to determine a maximum geological age of RH1. In this paper we report on the technical details of the EPR analyses and our resultant chronometric age estimates for the fossil bovid tooth recovered in the Cisanca deposit.

\section{RADIOMETRIC AGE ESTIMATES}

Upon discovery in the field, the bovid teeth and approximately $2 \mathrm{~kg}$ of surrounding matrix were immediately double-bagged in opaque and airtight plastic to prevent exposure to sunlight and to retain sedimentary moisture. These samples were transported intact (avoiding radiation sources such as airport X-ray machinery) from Java back to the U.S. for preparation and analysis.

\subsection{RADIOISOTOPIC ANALYSIS}

Radioisotopic analyses were performed at the Oak Ridge National Laboratory (ORNL) Dosimetry Applications Research (DOSAR) facility, and added radiation doses were provided at the ORNL Co-60 Irradiation Facility. Electron paramagnetic resonance analyses (as described in Weeks et al. [2003]) were conducted in laboratories of the ORNL Solid State Division.

Radioisotope activity concentrations in samples of tooth components and contextual material were determined by gamma-ray spectrometry for ${ }^{40} \mathrm{~K}$ and for representative isotopes of the ${ }^{232} \mathrm{Th}$ and ${ }^{238} \mathrm{U}$ radioactive decay series. Contextual material was analyzed without treatment. Interior enamel from a single tooth was analyzed in small pieces, approximately $1 \times 1 \times 10 \mathrm{~mm}^{3}$. The spectrometry system consisted of high-purity germanium (HPGe) detectors coupled for data acquisition to a personal computer through multi-channel analyzers and 
spectroscopic linear amplifiers. Two types of HPGe detectors were used: (1) a detector with planar geometry ${ }^{1}$ for low-energy (less than about $300 \mathrm{keV}$ ) photons, and (2) a detector with coaxial geometry for higher-energy photons. The gamma-ray spectra were collected for 72 hours over the energy range $0.05-1.8 \mathrm{MeV}$, and individual radioisotopes were identified using Genie ${ }^{\mathcal{O}}$ VMS, v. 4.0 (Canberra Nuclear Products), an automated peak-search routine.

\subsection{IRRADIATION}

Samples of interior enamel cut into approximately $1 \times 1 \times 10-\mathrm{mm}^{3}$ bars were irradiated in sealed quartz EPR tubes $(4.00 \mathrm{~mm}$ outside diameter, $2.92 \mathrm{~mm}$ inside diameter) placed within a quartz cylinder which held the tubes upright in an irradiator containing $c a .1,180 \mathrm{Ci}$ of ${ }^{60} \mathrm{Co}$ arranged to provide a uniform dose rate in the sample volume. Exposure rates ${ }^{2}$ were approximately $9 \times 10^{4} \mathrm{R} / \mathrm{h}$, based on the initial exposure rate provided by the manufacturer. Delivered sample doses are estimated to be $95.3 \%$ of the air dose, based on mass energyabsorption coefficients in air published by the National Institute of Standards and Technology (Hubbel and Seltzer, 1997) and in quartz (calculated as the weighted sum of coefficients for the constituent elements), and are presented with results of the EPR analysis.

\subsection{DETERMINATION OF AGE}

Radionuclide activity concentrations in the samples, determined by gamma-ray spectrometry, are shown in Table 1. The spectrum-analyzing software provides a radionuclide activity estimate and error bounds based on the intensity of each principal gamma emission ${ }^{3}$ in a particular isotope's photon spectrum.

Sample averages of activity concentration for each radioisotope were calculated as the average of concentrations reported by the software (based on individual concentration estimates from photon emissions at different energies specific for that isotope), weighted for the relative abundances of the photons on which the individual concentrations were based. These concentration averages are reported in the table, along with the propagated measurement uncertainties. The most likely activity concentrations in the ${ }^{238} \mathrm{U}$ and ${ }^{232} \mathrm{Th}$ decay series were taken to be the activity of either the parent or one of the progeny (which should be approximately equal under secular equilibrium conditions, but which may be dissimilar if separation processes have occurred) based primarily on the relative uncertainty in the measurement. Activities were converted to mass using specific activities of the pure radionuclides from Table 2. The resulting mass concentrations are reported in Table 3. Table 4 shows published dose rate conversion factors (Mejdahl and Wintle, 1984) used with the mass concentrations to obtain corresponding radiation dose rates to the sample, shown in Table 5. The table shows that the estimate of contextual effective radiation dose rate, from radionuclides incorporated in the sample and surrounding matrix, is $(4,940 \pm 85) \mu \mathrm{Gy} / \mathrm{y}$.

Five radiation-sensitive peaks and inflections in the first derivative of the EPR spectrum were used to estimate the sample age and are labeled ' $A$ ' through ' $E$ ' in Figure 1. Table 6 shows the amplitudes of these features, measured from a base line determined by the endpoints of the curve in the figure, in the sample as found and after added radiation dose. (The sign of the amplitude relative to the baseline is irrelevant.) Plots of the resonance peak amplitudes as a function of added dose to the sample are shown in Figure 2. The radiation dose accumulated by the sample during its burial is estimated as the ratio of the $y$-intercept to the slope, using the radiation response from each of the five inflections (shoulders or maxima). Regression parameters for the

${ }^{1}$ ORTEC $^{\circledR}$ GLP Series Planar Low-Energy Photon Spectrometer (LEPS)

${ }^{2} \mathrm{~A}$ series of irradiations was performed over five months. The ${ }^{60} \mathrm{Co}$ exposure rate ranged from $9.06 \times 10^{4} \mathrm{R} / \mathrm{h}$ to $8.57 \times 10^{4} \mathrm{R} / \mathrm{h}$ over the course of these irradiations because of source depletion by radioactive decay.

${ }^{3}$ Principal gamma emissions are generally those with greatest abundance. Less abundant emissions may be used if competing emissions from another radioisotope are close enough in energy to compromise resolution of the spectrum. 


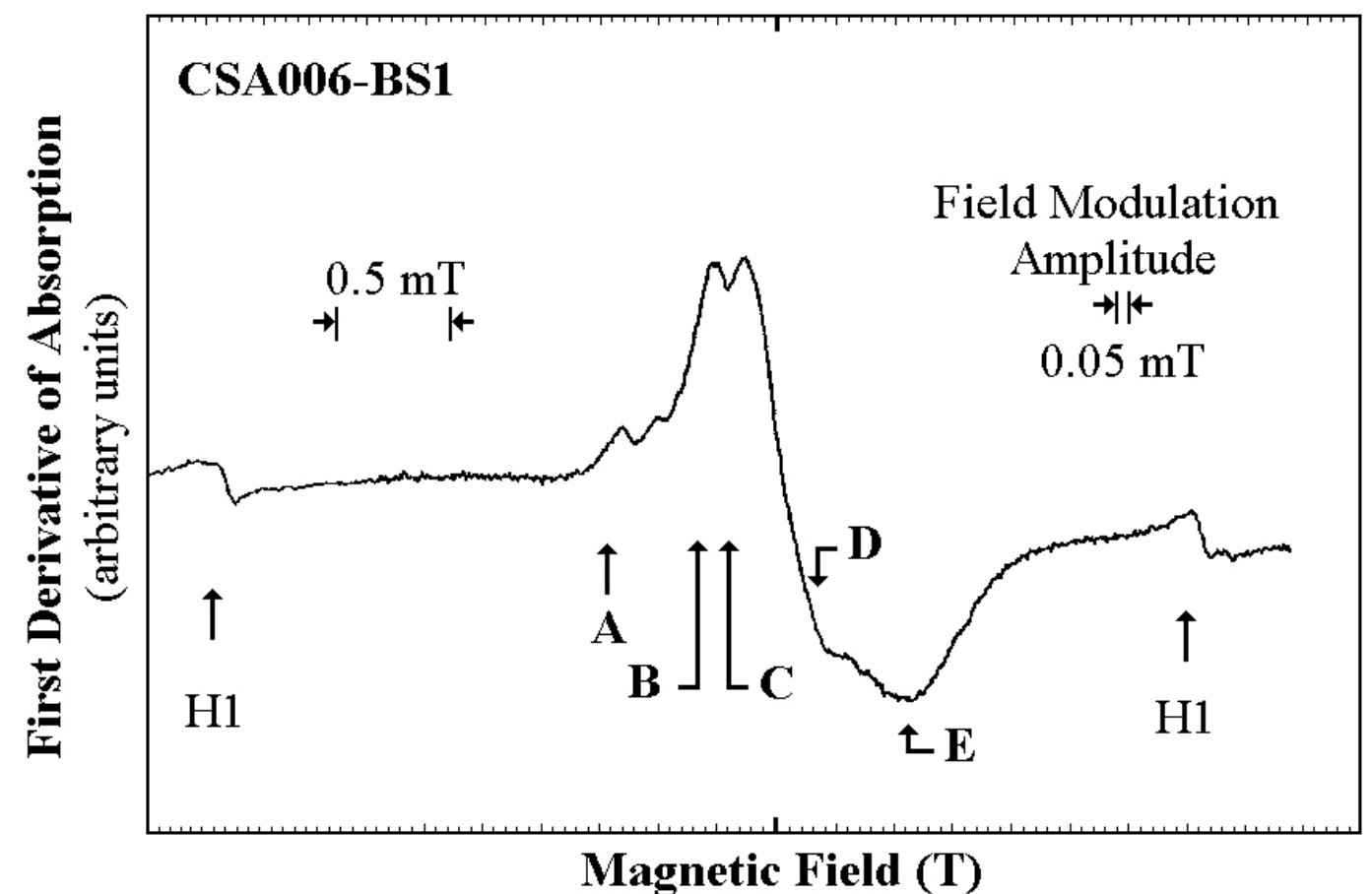

Figure 1. EPR spectrum of a bar sample from a fossil bovid tooth, as recovered. Spectral features used in radiometric age estimation are marked by arrows, with $g=2.0062$ (for the field at $\mathbf{A}$ ), $g=2.0038(\mathbf{B}), g=2.0030(\mathbf{C}), g=2.0009$ (D) and $g=1.9980$ (E) (all values $\pm 0.0005)$. The $\mathbf{H} 1$ doublet ( $g=2.0169$ and $g=1.9906)$ was not used to estimate age of the sample. The spectrometer parameters are sweep range, $5 \mathrm{mT}$; field modulation frequency, $100 \mathrm{kHz}$ and amplitude $0.05 \mathrm{mT}$; amplifier gain, $10 \times 10^{3}$; microwave power, $2 \mathrm{~mW}$.

plots of Figure 2 and estimates of the dose accumulated during burial are provided in Table 7. A single estimate of the accumulated dose, expressed as the average and sample standard deviation of the five individual estimates in Table 7, is $(2,550 \pm 990) \mathrm{Gy}$.

The sample burial time and its associated uncertainty are estimated, using the ratio of accumulated dose to the contextual effective dose rate and the propagated uncertainties, to be $(5.16 \pm 2.01) \times 10^{5}$ years.

\subsection{SOURCES OF UNCERTAINTY OR ERROR IN THE DETERMINATION OF AGE}

The estimate of sample age is taken as the ratio of accumulated ionizing radiation dose in the sample and the contextual dose rate (from terrestrial radionuclides in the sample and surrounding material). This assumes that burial was immediate (compared with the age of the sample), that dose rate was constant with time, and that the dose response is linear. There are several potential sources of error in these assumptions. A comprehensive discussion of many of the factors influencing estimates of sample age by the closely related EPR and thermoluminescence techniques can be found in the review by Mejdahl and Wintle (1984). Our contextual dose rate, for instance, does not include contributions from cosmic radiation or the terrestrial radionuclide ${ }^{87} \mathrm{Rb}$. Cosmic radiation might contribute on the order of $5 \%$ to the total dose rate, and ${ }^{87} \mathrm{Rb}$, around $1 \%$, with the effect that the age estimate is lowered by about $5 \%$. Further, of the radiation sources considered, only ${ }^{40} \mathrm{~K}$ is assumed to already have been incorporated in the sample with the observed concentrations at the time of burial. Uranium and thorium present in the fossil tooth are assumed to have migrated into the tooth from the surrounding material. We do not know this migration rate, and so we make the simplistic assumption that the mean concentration of uranium, thorium and their radioactive decay 


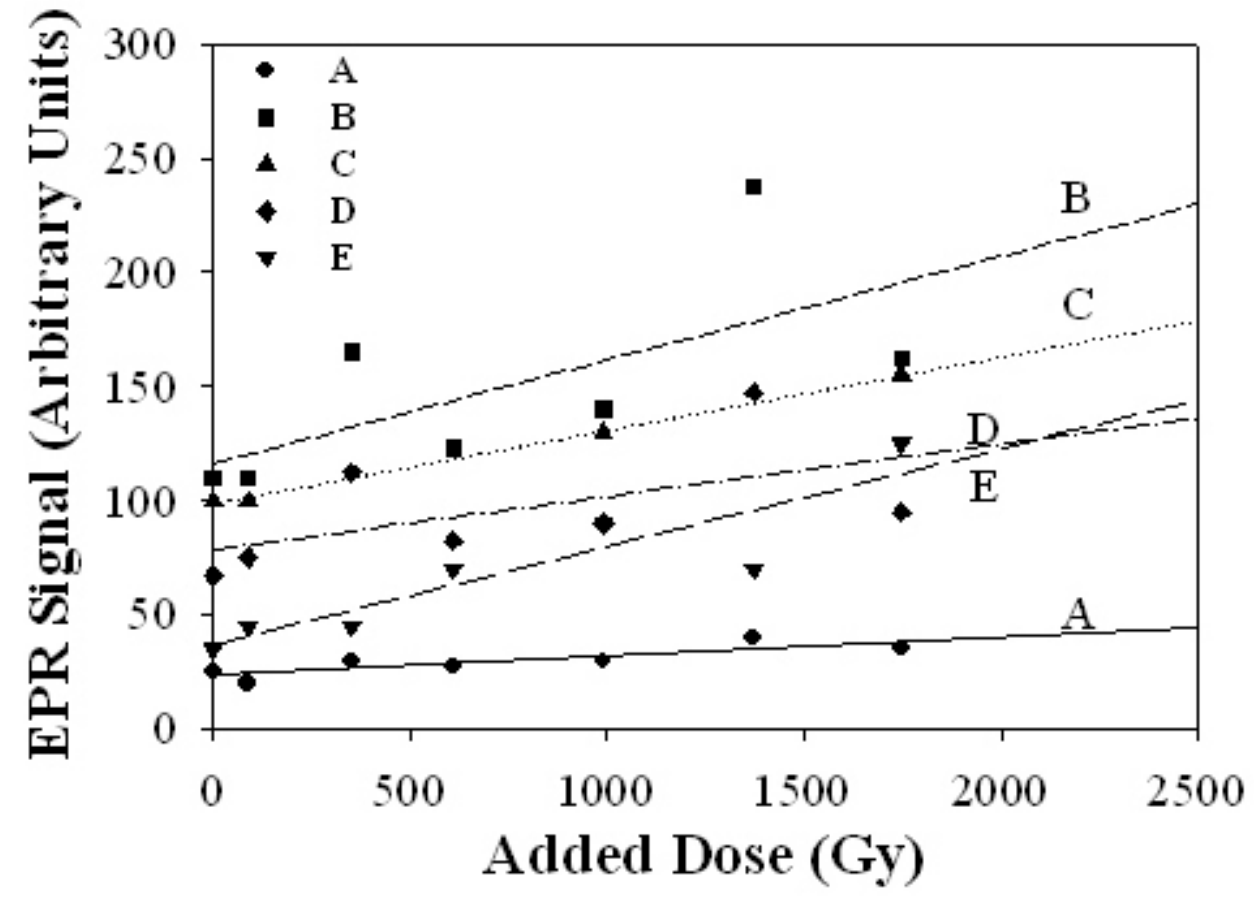

Figure 2. Electron paramagnetic resonance response of fossil tooth enamel to ionizing radiation. Peaks and inflections in the first derivative of the absorption, 'A' through 'E', are identified in Figure 1. Responses correspond to a modulation amplitude of $0.05 \mathrm{mT}(0.5 \mathrm{G})$ and gain $=10^{4}$. The response for an added dose of zero $(0)$ is the response of the enamel from accumulated radiation exposure during burial to the time of excavation.

progeny (and, therefore, the mean dose rate from these materials, Table 5) in the sample is half that observed in the laboratory. Also affecting the estimate of dose rate is the potential migration of radionuclides out of the sample matrix. We note from Table 1 that no ${ }^{210} \mathrm{~Pb}$ is detected in either the sample or its surrounding soil. This means either that its concentrations are below the level at which our gamma-spectrometry peak-search software concludes that it is present, or else that it or a precursor radionuclide has been removed by chemical or physical processes. We see, however, that ${ }^{214} \mathrm{~Pb}$ is present in both sample and soil at activity concentrations reasonably close to those of the parent ${ }^{238} \mathrm{U}$, indicating that ${ }^{222} \mathrm{Rn}$ did not migrate out of the matrix. ${ }^{4} \mathrm{We}$ assume on this basis that the full value of dose conversion factors for ${ }^{238} \mathrm{U}$ and it progeny are appropriate. There is also no detected ${ }^{208} \mathrm{Tl}$ in the sample; however, a small amount of ${ }^{212} \mathrm{~Pb}$ is detected, and we assume the presence of ${ }^{232} \mathrm{Th}$ at the activity concentration of ${ }^{212} \mathrm{~Pb}$.

\footnotetext{
${ }^{4}$ An additional complication involving ${ }^{222} \mathrm{Rn}$ and ${ }^{220} \mathrm{Rn}$ is that their concentrations are potentially highly variable over time in the contextual materials surrounding the fossil. (This variability is most often associated with the presence or absence of diffusion channels through which the gases can migrate, and the availability of these channels can be significantly affected by the amount of water in the soil or the nature of additional layers that may be overlain at the surface.) Radon may migrate either into or out of the fossil, depending on the direction of the concentration gradient.
} 
Examination of Table 7 reveals that four of the five radiation-sensitive EPR spectral features ('A' through 'D') give good agreement in the estimate of accumulated dose in the sample, but that the fifth resonance ('E') yields an estimate that is less than a third the value of the others. The averaged estimate of accumulated dose from resonances ' $A$ ' through ' $D$ ', excluding the ' $E$ ' resonance as an outlier, is $(2,966 \pm 370)$ Gy, with a resulting sample burial time of $(6.06 \pm 0.76) \times 10^{5} \mathrm{y}$. We have chosen to include information from the ' $\mathrm{E}$ ' resonance in our analysis, since the reasons for its quite different radiation response are not understood.

Finally, we have recently reported (Weeks et al., 2003) the presence of hyperfine components originally attributed to an alanine radical in the EPR spectra (identified as the "H1 doublet" in Figure 1) of the fossil bovid teeth from Cisanca. We were able to experimentally replicate these features in modern equine dental samples by heating the specimens at temperatures greater than $100^{\circ} \mathrm{C}$ for 30 minutes. We conclude that the Cisanca bovid dental fossils were therefore heated at some point during their depositional history, thus their EPR ages reported here are very likely "younger than the actual age." (Weeks et al., 2003, p. 9888).

\section{CONCLUSIONS}

A fossil bovid tooth found in association with the first fossil hominid tooth recovered from West Java, Indonesia, was analyzed using EPR techniques and found to have an approximate age of $(5.16 \pm$

$2.01) \times 10^{5}$ years. However, because there is evidence of post-depositional heating of the bovid tooth, this age estimate should be interpreted as the minimum age. It is therefore likely that the tooth is older. 
Table 1. Radionuclide activity concentrations (pCi/g) in tooth enamel and contextual materials ${ }^{a}$

\begin{tabular}{|c|c|c|c|c|c|c|}
\hline & \multirow[b]{2}{*}{${ }^{40} \mathrm{~K}$} & \multicolumn{3}{|c|}{${ }^{238} \mathrm{U}$ Decay chain } & \multicolumn{2}{|c|}{${ }^{232} \mathrm{Th}$ Decay chain } \\
\hline & & ${ }^{238} \mathrm{U}$ & ${ }^{214} \mathrm{~Pb}$ & ${ }^{210} \mathrm{~Pb}$ & ${ }^{212} \mathrm{~Pb}$ & ${ }^{208} \mathrm{Tl}$ \\
\hline Enamel & $0.63 \pm 0.22$ & $5.23 \pm 0.12$ & $4.51 \pm 0.07$ & $\mathrm{ND}^{b}$ & $0.06 \pm 0.02$ & $\mathrm{ND}^{b}$ \\
\hline Soil & $6.06 \pm 0.20$ & $0.31 \pm 0.10$ & $0.33 \pm 0.01$ & $\mathrm{ND}^{b}$ & $0.35 \pm 0.01$ & $0.25 \pm 0.04$ \\
\hline
\end{tabular}

${ }^{a}$ Estimates of activity concentration and the associated confidence interval are made at each photon energy for radionuclides with multiple photon emissions. Values given here are the concentration average (weighted for the photon abundances) \pm the sample average standard deviation. Uncertainties in individual concentration estimates are propagated in calculating the sample average standard deviation. No shielding corrections for varying densities have been incorporated.

${ }^{b} \mathrm{ND}=$ not detected.

Table 2. Specific activities of the pure radionuclides

\begin{tabular}{ccc}
\hline Radionuclide & $\begin{array}{c}\text { Half-Life } \\
(\mathrm{y})\end{array}$ & $\begin{array}{c}\text { Specific activity } \\
(\mathrm{pCi} / \mathrm{g})\end{array}$ \\
\hline${ }^{40} \mathrm{~K}$ & $1.277 \times 10^{9}$ & $6.999 \times 10^{6}$ \\
${ }^{232} \mathrm{Th}$ & $1.405 \times 10^{10}$ & $1.097 \times 10^{5}$ \\
${ }^{238} \mathrm{U}$ & $4.468 \times 10^{9}$ & $3.362 \times 10^{5}$ \\
\hline
\end{tabular}


Table 3. Radionuclide mass concentrations used for dose rate estimates

\begin{tabular}{cccc}
\hline $\begin{array}{c}\text { Radionuclide or } \\
\text { series }\end{array}$ & $\begin{array}{c}\text { Sample activity } \\
\text { concentration } \\
(\mathrm{pCi} / \mathrm{g})\end{array}$ & $\begin{array}{c}\text { Mass } \\
\text { concentration } \\
(\mathrm{ppm})\end{array}$ & Based on $^{a}$ \\
\hline${ }^{40} \mathrm{In}$ Soil & & \\
${ }^{232} \mathrm{Th}$ & 6.06 & 0.87 & $\left({ }^{40} \mathrm{~K}\right)$ \\
${ }^{238} \mathrm{U}$ & 0.35 & 0.19 & ${ }^{212} \mathrm{~Pb}$ \\
& 0.33 & & \\
& & & \\
& & & \\
& & & \\
& & & \\
${ }^{40} \mathrm{~K}$ & 0.63 & 0.09 & $\left({ }^{40} \mathrm{~K}\right)$ \\
${ }^{232} \mathrm{Th}$ & 0.06 & 0.55 & ${ }^{212} \mathrm{~Pb}$ \\
${ }^{238} \mathrm{U}$ & 5.23 & 15.56 & ${ }^{238} \mathrm{U}$ \\
\hline
\end{tabular}

${ }^{a}$ Secular equilibrium is assumed in determining equivalent masses of the parent ${ }^{232} \mathrm{Th}$ and ${ }^{238} \mathrm{U}$ from the activities of progeny reported in the gamma spectrometry analysis (Table 1 ) and the specific activities of the parents (Table 2). Confidence intervals, which are in the same ratios as those of activity concentrations, are not reported.

Table 4. Dose rate conversions for the naturally occurring radionuclides

\begin{tabular}{lcccc}
\hline & & \multicolumn{3}{c}{ Dose rate $(\mu \mathrm{Gy} / \mathrm{a})$} \\
\cline { 3 - 5 } Radionuclide & Concentration & $\alpha$ & $\beta$ & $\gamma$ \\
\hline $\begin{array}{l}\text { Thorium series } \\
\text { (No thoron loss) }\end{array}$ & $1 \mathrm{ppm}^{232} \mathrm{Th}$ & 738 & 28.6 & 51.4 \\
$\begin{array}{l}\text { Uranium series } \\
\text { (No radon loss) }\end{array}$ & $1 \mathrm{ppm}^{238} \mathrm{U}$ & 2,783 & 146.2 & 114.8 \\
Natural potassium $^{a}$ & $1 \mathrm{ppm}^{40} \mathrm{~K}$ & -- & 697.7 & 203 \\
\hline
\end{tabular}

Note: Adapted from Mejdahl and Wintle (1984)

${ }^{a}$ Based on values for $1 \%$ natural potassium; $1 \% \mathrm{~K}_{\text {nat }}=$ $1.19 \mathrm{ppm}^{40} \mathrm{~K}$. 
Table 5. Sample dose rate estimate from incorporated radionuclides

Dose rate $(\mu \mathrm{Gy} / \mathrm{y})^{a}$

$\begin{array}{cc}\text { Raw }^{b} & \text { Effective }^{c} \\ & \\ 186 \pm 6 & 186 \pm 6 \\ 230 \pm 5 & 230 \pm 5 \\ 215 \pm 34 & 215 \pm 34\end{array}$

$\beta$ (from interior enamel)

$\begin{array}{lcc}{ }^{40} \mathrm{~K} & -0- & -0- \\ { }^{232} \mathrm{Th} & -0- & -0- \\ { }^{238} \mathrm{U} & 91 \pm 61 & 46 \pm 30\end{array}$

$\alpha$ (from interior enamel)

$\begin{array}{lcc}{ }^{232} \mathrm{Th} & -0- & -0- \\ { }^{238} \mathrm{U} & 1,739 \pm 1,159 & 130 \pm 87\end{array}$

TOTAL $\quad 2,500 \pm 1,200 \quad 810 \pm 100$

${ }^{a}$ The Total is rounded to the appropriate number of significant figures. Individual components of dose are expressed to the units digit for purposes of summation. Uncertainties expressed for individual dose contributions are 1 standard deviation and are in the same ratios as in the associated activity concentrations of Table 1; uncertainty in the Total is from the sum of variances of individual values.

${ }^{b}$ The estimated radiological dose rate from natural radionuclides in the sample and its burial matrix at the time of discovery.

${ }^{c}$ The estimated dose rate, corrected for dependence on time and radiation quality, corresponding to the observed EPR signal. An EPR efficiency of 0.15 is applied to the $\alpha$ dose, with the assumption that $\alpha$-particle efficiency in producing EPR signal is the same as for producing thermoluminescence (Mejdahl and Wintle, 1984). The mean concentration of ${ }^{232} \mathrm{Th}$ and ${ }^{238} \mathrm{U}$ in the interior enamel is assumed to be half the present amount, accounting for migration from the contextual material over time. (Incorporation of ${ }^{40} \mathrm{~K}$ into the interior enamel is assumed to have occurred in the living animal, and not by migration from the burial matrix.) 
Table 6. Radiation response of excavated tooth enamel for five radio-sensitive EPR resonances designated ' $A$ ' through ' $E$ '

\begin{tabular}{|c|c|c|c|c|c|}
\hline \multirow{2}{*}{$\begin{array}{c}\text { Delivered } \\
\text { dose } \\
(\mathrm{Gy})\end{array}$} & \multicolumn{5}{|c|}{ Peak amplitude, normalized to unit mass $\left(\mathrm{g}^{-1}\right)$} \\
\hline & $\mathrm{A}$ & $\mathrm{B}$ & $\mathrm{C}$ & $\mathrm{D}$ & $\mathrm{E}$ \\
\hline 0.0 & 4 & 11.75 & 6.75 & 6 & 4.75 \\
\hline 88.2 & 4 & 14 & 8 & 8 & 5.5 \\
\hline 352 & 5 & 16 & 10 & 10 & 7.5 \\
\hline 609 & 4.5 & 13.5 & 10 & 8 & 10.5 \\
\hline 992 & 6 & 25.5 & 18 & 17 & 11.5 \\
\hline 1370 & 7 & 29 & 21 & 19 & 15 \\
\hline 1750 & 7.5 & 33.5 & 23 & 21 & 16 \\
\hline
\end{tabular}

Table 7. Regression parameters ${ }^{a}$ from the dose-response curves of Figure 1

\begin{tabular}{ccccc}
\hline $\begin{array}{c}\text { EPR } \\
\text { feature }\end{array}$ & $\begin{array}{c}y \text {-Intercept } \\
\text { (arbitrary units) }\end{array}$ & $\begin{array}{c}\text { Slope } \\
\left(\mathrm{Gy}^{-1}\right), \times 10^{2}\end{array}$ & $\begin{array}{c}\text { Regression } \\
\text { coefficient, } \\
r^{2}\end{array}$ & $\begin{array}{c}\text { Dose accumulated } \\
\text { since burial } \\
(\mathrm{Gy}), \times 10^{-3}\end{array}$ \\
\hline $\mathrm{A}$ & $3.8_{8}$ & $0.21_{0}$ & 0.946 & $1.8_{5}$ \\
$\mathrm{~B}$ & $11 ._{1}$ & $1.2_{6}$ & 0.921 & $0.88_{1}$ \\
$\mathrm{C}$ & $6.5_{4}$ & $0.98_{7}$ & 0.958 & $0.66_{3}$ \\
$\mathrm{D}$ & $6.2_{1}$ & $0.88_{3}$ & 0.913 & $0.70_{3}$ \\
$\mathrm{E}$ & $5.2_{3}$ & $0.66_{1}$ & 0.974 & $0.79_{1}$ \\
\hline
\end{tabular}

${ }^{a}$ A subscripted final unit is not significant, but is used in calculations. 


\section{REFERENCES}

Cetin, O., Ozer, A.M., Weiser, A. 1994. "ESR dating of tooth enamel from Karain excavation (Antalya, Turkey)," Quaternary Geochronology (Quaternary Science Reviews) 13, 661-669.

Curnoe, D., Grün, R., Taylor, L., Thackeray, F. 2001. "Direct ESR dating of a Pliocene hominin from Swartkrans," J. Hum. Evol. 40, 379-391.

Geyh, M.A., Schleicher, H. 1990. Absolute Age Determination, Springer Verlag, Berlin.

Grün, R., Schwarcz H.P., Zymela, S. 1987. "Electron spin resonance dating of tooth enamel," Canadian Journal of Earth Science 24, 1022-1037.

Hubbell, J.H., Seltzer, S. M. 1997. Tables of X-Ray Mass Attenuation Coefficients and Mass EnergyAbsorption Coefficients (version 1.03), National Institute of Standards and Technology, Gaithersburg, MD.

Kramer, A., Djubiantono, T., Aziz, F., Bogard, J.S., Weeks, R.A., Weinand, D.C., Hames, W.E., Elam, J.M., Durband, A.C., Agus 2004, "The first hominid fossil recovered from West Java, Indonesia," Journal of Human Evolution, (in preparation).

Kramer A., Elam, J.M., Djubiantono, T., Aziz, F., Hames, W.E. 2000. "1999 Excavations in the Rancah District, West Java, Indonesia,” American Journal of Physical Anthropology, 30 (Suppl.), 201.

Kramer A., Elam, J.M., Durband, A.C., Weinand, D.C., Djubiantono, T., Aziz, F., Hames, W.E. 2002. "Radiometric ages of faunal and hominid-bearing sites in West Java: preliminary results from the 1999 field season," Abstracts of the Seventeenth Congress of the Indo-Pacific Prehistory Association, Academia Sinica, Taipei, Taiwan, R.O.C., pp. 116-117.

Kramer, A., Weinand, D.C., Djubiantono, T., Aziz, F., Hames, W.E., Elam, J.M., Bogard, J.S., Weeks, R.A., Sumarinda, I., Agus, Durband, A.C. 2001. "Multidisciplinary paleoanthropological excavations in the Rancah district of West Java: report from the 1999 field season," Special Publication 27, Geological Research and Development Centre (Bandung, Indonesia) pp. 67-79.

Mejdahl, V., Wintle, A.G. 1984. "Thermoluminescence applied to age determination in archaeology and geology," in Horowitz, Y.S., (Ed.) Thermoluminescence and Thermoluminescent Dosimetry, Vol. III, CRC Press, Inc., Boca Raton, FL, pp. 133-190.

Schwarcz, H.P., Grün, R. 1993. "Electron spin resonance (ESR) dating of the origin of modern man," in Aitken, M.J., Stringer, C.B., Mellars, P.A., (Eds.), The Origin of Modern Humans and the Impact of Chronometric Dating, Princeton University Press, Princeton, NJ, pp. 40-48.

Weeks, R.A., Bogard, J.S., Elam, J.M., Weinand, D.C., Kramer, A. 2003. "Effects of thermal annealing on the radiation produced electron paramagnetic resonance spectra of bovine and equine tooth enamel: Fossil and modern," Journal of Applied Physics 93, 9880-9889.

Weinand, D.C., Elam, J.M., Durband, A.C., Kramer, A., Djubiantono, T., Aziz, F., Hames, W.E., Weeks, R.A., Bogard, J.S. 2000. "Electron Spin Resonance (ESR) Dating of fossil bovid teeth from Rancah, West Java,". Invited Paper presented at Towards Ahead: The Geological Museum in a Changing World, Bandung, West Java, Indonesia, August 23. 
ORNL/TM-2004/85

\section{INTERNAL DISTRIBUTION}

1. J. S. Bogard

2. M. E. Murray
3. Central Research Library

4. ORNL Laboratory Records - RC

5-6. Laboratory Records - OSTI

\section{EXTERNAL DISTRIBUTION}

7. J. M. Elam, Department of Anthropology, University of Tennessee, Knoxville TN 37996-0720

8. A. Kramer, Department of Anthropology, University of Tennessee, Knoxville TN 37996-0720

9. R. A. Weeks, 331 South Shore Drive, Greenback, TN 37742

10. D. C. Weinand, Department of Anthropology, University of Tennessee, Knoxville TN 37996-0720 